\title{
GMR
}

\section{Expressed sequence tags related to nitrogen metabolism in maize inoculated with Azospirillum brasilense}

\author{
L. Pereira-Defilippi, E.M. Pereira, F.M. Silva and G.V. Moro \\ Departamento de Produção Vegetal, Faculdade de Ciências Agrárias e Veterinárias, \\ Universidade Estadual de São Paulo "Júlio de Mesquita Filho", Jaboticabal, SP, Brasil \\ Corresponding author: L. Pereira-Defilippi \\ E-mail: liviapdefilippi@gmail.com
}

Genet. Mol. Res. 16 (2): gmr16029682

Received March 23, 2017

Accepted April 3, 2017

Published May 31, 2017

DOI http://dx.doi.org/10.4238/gmr16029682

Copyright (C) 2017 The Authors. This is an open-access article distributed under the terms of the Creative Commons Attribution ShareAlike (CC BY-SA) 4.0 License.

\begin{abstract}
The relative quantitative real-time expression of two expressed sequence tags (ESTs) codifying for key enzymes in nitrogen metabolism in maize, nitrate reductase $(Z m N R)$, and glutamine synthetase (ZmGln1-3) was performed for genotypes inoculated with Azospirillum brasilense. Two commercial single-cross hybrids (AG7098 and 2B707) and two experimental synthetic varieties (V2 and V4) were raised under controlled greenhouse conditions, in six treatment groups corresponding to different forms of inoculation and different levels of nitrogen application by top-dressing. The genotypes presented distinct responses to inoculation with $A$. brasilense. Increases in the expression of $Z m N R$ were observed for the hybrids, while V4 only displayed a greater level of expression when the plants received nitrogenous fertilization by topdressing and there was no inoculation. The expression of the ZmGln1$3 \mathrm{EST}$ was induced by $A$. brasilense in the hybrids and the variety V4. In contrast, the variety $\mathrm{V} 2$ did not respond to inoculation.
\end{abstract}

Key words: Zea mays L.; Nitrate reductase; Glutamine synthetase; qPCR 


\section{INTRODUCTION}

The cultivation of maize (Zea mays L.) occurs over many regions of the world, under the most varied climatic and soil conditions, consequently, is affected by various abiotic factors. Important among these is low soil fertility, principally associated with nitrogen $(\mathrm{N})$ (Lana et al., 2012). This scenario leads to a system of agriculture that is highly dependent on chemical fertilizers, to maintain high yields (Walker et al., 2012). Nitrogen is a key macronutrient for plant development and reproduction (Bernard and Habash, 2009), and since the cultivation of maize is one of the most demanding on $\mathrm{N}$, the provision of $\mathrm{N}$ has become an important tool for increasing maize productivity over recent decades (Hirel et al., 2001). However, the high cost of nitrogenous fertilizers has emphatically contributed to increases in production costs.

Within this context, it is important to enable more efficient production systems, reducing the $\mathrm{N}$ fertilization. The use of rhizobacteria, plant growth promoters, which are capable of fixing $\mathrm{N}$ and increasing the productivity of maize, has been widely studied. Bacteria of the genus Azospirillum spp have these characteristics, for they can associate themselves with the roots of non-leguminous plants and deliver benefits to the crops. Johanna Döbereiner reported these facts decades ago and, since then, various studies have been conducted proving the benefits of the rhizobacteria-maize interaction, with positive influences on parameters such as plant growth, development, production of grains, and biomass, as well as $\mathrm{N}$ content. The observed benefits in plants inoculated with Azospirillum spp have been attributed to various mechanisms of action, including the biological fixation of N(BFN) and the production of growth-promoting hormones (Dalla Santa et al., 2004; Baldani and Baldani, 2005; Hungria et al., 2010).

The sources of $\mathrm{N}$ absorbed by plants are nitrate $\left(\mathrm{NO}_{3}^{-}\right)$and ammonium $\left(\mathrm{NH}_{4}^{+}\right)$. So that $\mathrm{N}$ absorbed as $\mathrm{NO}_{3}{ }^{-}$can be assimilated and converted into amino acids, reduction of the $\mathrm{NO}_{3}^{-}$to $\mathrm{NH}_{4}^{+}$is necessary. In a first step, $\mathrm{NO}_{3}^{-}$is reduced to nitrite $\left(\mathrm{NO}_{2}^{-}\right)$. In a subsequent step, $\mathrm{NH}_{4}^{+}$generated from nitrite, or by photorespiration, recycling of amino acids, or through BFN is metabolized by the complex GS/GOGAT (glutamine synthetase/glutamate synthetase) (Buchanan et al., 2000; Masclaux-Daubresse et al., 2010). Two isoforms of GS have been characterized in higher plants, GS1, located in the cytosol, and GS2, found in the plastids. Both play key roles in the assimilation of $\mathrm{NH}_{4}^{+}$, although the cytosolic enzymes (GS1) are principally active, for they act in the assimilation of ammonium from several different sources, including $\mathrm{NH}_{4}^{+}$produced in BFN (Li et al., 1993; Bernard and Habash, 2009).

In maize, the assimilation of $\mathrm{NO}_{3}^{-}$represents a means of metabolizing $\mathrm{N}$, and so is relevant to agricultural systems that use low or high technology (Morrison et al., 2010). The expression of gene transcripts that codify nitrate reductase (NR) has been related to the efficiency with which a plant reduces $\mathrm{NO}_{3}^{-}$(Masclaux et al., 2000). Correlations between the $\mathrm{N}$ content, chlorophyll content, concentration of soluble proteins, and GS activity have been verified with QTL (quantitative trait loci) in maize plants having been found for the weight of 1000 grains corresponding to two loci of GS1 ( $g \ln 1-3$ and $g \ln 1-4)$ (Hirel et al., 2001, 2005a,b; Martin et al., 2006). Also for maize, through quantification of the RNAs of the five genes of GS1 and GS2 in nine types of plant tissue, a distinct expression profile has been observed for each of the transcripts. Two genes that codify GS1, $g \ln 1-3$ and $g \ln 1-5$, presented a level of transcript expression that was significantly detectable in all the types of tissue, including cell cultures, leaf veins, aerial parts of seedlings, roots, root tips, endosperm in development, new ears, pollen, and tassel (Li et al., 1993).

Genetics and Molecular Research 16 (2): gmr16029682 
The results reported in the studies related to the enzymes described above and their transcripts are promising. However, there is a need for more studies to explore the expression profile of these genes in maize inoculated with Azospirillum brasilense. A specific justification for these studies is the building of knowledge concerning the factors that affect the expression of the genes that codify these enzymes. The processes catalyzed by the enzymes are of primary importance for they are relevant to the metabolism of a nutrient that acts as a limiter in maize production. The chances of success in efforts to improve the efficiency of $\mathrm{N}$ assimilation will be improved by a greater level of understanding of this complex process.

We aimed with this study to verify the effect of inoculations with $A$. brasilense and the influence that the mode of inoculation had upon the quantitative time profile for the expression of the two ESTs (expressed sequence tags) related to the metabolism of Nin maize.

\section{MATERIAL AND METHODS}

\section{Plant material}

Two single-cross commercial hybrids of maize (AG7098 and 2B707) and two synthetic experimental varieties (V2 and V4) were raised in a greenhouse at the Department of Plant Production of the College of Agrarian and Veterinary Sciences of the State University of São Paulo in Jaboticabal, SP (FCAV - UNESP). Both temperature $\left(25^{\circ} \pm 3^{\circ} \mathrm{C}\right)$ and relative humidity $(\sim 80 \%)$ were controlled. The seeds of the four genotypes were supplied pre-treated with a fungicide and an insecticide by the companies that produced the seeds. The seeds were sown in pots filled with a red eutrophic Latosol with a clayey texture, at a rate of $12 \mathrm{seeds} / \mathrm{dm}^{-3}$.

\section{Inoculation}

The inoculation with $A$. brasilense was performed utilizing a commercial product, which contained the strains AbV5 and AbV6 (QualyFix Gramínea, Brasilquímica). Dosage rates were as recommended by the manufacturer, and corresponded to $100 \mathrm{~mL}$ per $25 \mathrm{~kg}$ seeds for inoculation via seeds and $600 \mathrm{~mL} / \mathrm{ha}$ for inoculation via soil.

\section{Greenhouse bioassays}

The experiment was conducted in a greenhouse, with seeds/plants of each of the four genotypes being assigned to the following treatment groups: 1) Control, without inoculation and application of N, 2) Inoculation of the seeds with A. brasilense just before sewing (b.s.), without application of N, 3) Inoculation of the seeds b.s., with $N$ top-dressing at a rate of $100 \mathrm{~kg} /$ ha $N$, 4) Inoculation 30 days after emergence (d.a.e.), without application of N, 5) Inoculation at 30 d.a.e., with top-dressing of $100 \mathrm{~kg} / \mathrm{ha} \mathrm{N}$, and 6) Top-dressing of $100 \mathrm{~kg} / \mathrm{ha} \mathrm{N}$, without inoculation. Three biological repetitions were performed for each genotype and treatment. For each repetition, four seeds were sown per pot, from which two plants were raised. The two raised plants constituted one experimental plot, corresponding to two pots for each treatment.

All the pots received a base fertilization with an N-P-K (8-28-16) formulation matching the needs established during an analysis of the fertility of the soil. For the treatment groups, which received $\mathrm{N}$ top-dressing, the $\mathrm{N}$ source utilized was urea ( $45 \%$ soluble $\mathrm{N})$. The pots received a uniform, daily irrigation.

Genetics and Molecular Research 16 (2): gmr16029682 
Samples were collected from the third totally expanded leaf, counted from the apex (Ferreira et al., 2002) of each plant within each plot. Sampling occurred 55 days after emergence (Ferreira et al., 2002; Roesch et al., 2005) when the plants bore 10 to 11 totally expanded leaves. The samples were wrapped in aluminum foil, labeled, and immediately submerged in liquid $\mathrm{N}$, before storage in an ultra-freezer at $-80^{\circ} \mathrm{C}$, until the isolation of the total RNA. In the isolation of the total RNA, the samples corresponding to each plot/genotype/ treatment were processed individually.

\section{RNA extraction and treatment with DNase}

Approximately $100 \mathrm{mg}$ of each sample was ground in a mortar with liquid N. Total RNA was extracted utilizing $1 \mathrm{~mL}$ TRIzol ${ }^{\circledR}$ Reagent (Invitrogen/Life Technologies, Carlsbad, CA, USA), according to the procedure described in the manual provided by the manufacturer. The resulting pellet was purified with the aid of a QIAGEN RNeasy Cleanup Kit (QIAGEN, Valencia, CA, USA), following the manufacturer's instructions. The samples of total RNA were treated with DNase I, RNase-free (Thermo Scientific, Pittsburgh, PA, USA), according to the manufacturer's instructions, to eliminate potential contamination with genomic DNA. The treatment was performed in a $20-\mu \mathrm{L}$ reactor, into which $2 \mu \mathrm{g}$ total RNA was added for each $2 \mathrm{U}$ DNase I, together with $2 \mu \mathrm{L} 10 \mathrm{X}$ buffer, and $2 \mathrm{U}$ RiboLock RNase Inhibitor. The reactor was incubated in a thermal cycler for $30 \mathrm{~min}$ at $37^{\circ} \mathrm{C}$. This incubation was followed by the addition of $1 \mu \mathrm{L} 50 \mathrm{mM}$, and incubation at $65^{\circ} \mathrm{C}$ for $5 \mathrm{~min}$. The integrity of the RNA was visualized on an agarose gel $(1.2 \% \mathrm{~m} / \mathrm{v})$ and inspected for the absence of genomic DNA. Estimation of the total RNA in all of the samples was performed with a NanoDrop ${ }^{\mathrm{TM}} 1000$ spectrophotometer (Thermo Scientific, Wilmington, DE, USA).

\section{cDNA preparation}

cDNA was synthesized for each treatment, utilizing a RevertAid First Strand cDNA Synthesis Kit (Thermo Scientific, Pittsburgh, PA, USA), following the protocol suggested by the manufacturer. The RT-PCR (reverse transcription polymerase chain reaction) was conducted in tubes containing $2 \mu \mathrm{g}$ total RNA, $1 \mu \mathrm{L} 100 \mathrm{mM}$ oligo (dT) $)_{18}$ primers, with the reaction volume made up to $12 \mu \mathrm{L}$ with ultra-pure water free of nucleases. The tubes were incubated at $65^{\circ} \mathrm{C}$ for $5 \mathrm{~min}$, after which they were immediately chilled in an ice bath. Chilling was followed by the addition of $4 \mu \mathrm{L} 5 \mathrm{X}$ buffer, $1 \mu \mathrm{L}$ RiboLock RNase Inhibitor $(20 \mathrm{U} / \mu \mathrm{L})$, $2 \mu \mathrm{L} 10 \mathrm{mM}$ dNTP Mix, $1 \mu \mathrm{L}$ RevertAid M-MuLV Reverse Transcriptase (200 U/ $\mu \mathrm{L})$, giving a total volume of $20 \mu \mathrm{L}$. Upon completion of the synthesis reaction, the product cDNAs were stored in an ultra-freezer at $-70^{\circ} \mathrm{C}$.

\section{Real-time qPCR of ESTs related to N metabolism}

\section{Design of primers for NR and glutamine synthetase}

The primers utilized in this study were designed with the aid of the Primer Express v.2.1 program (Applied Biosystems, Foster City, CA, USA), within the parameters considered acceptable for real-time quantitative PCR, established for the generation of amplification products with 50 to $150 \mathrm{bp}$ (Primer Express Software v.2.1). Primers specific for the ESTs of

Genetics and Molecular Research 16 (2): gmr16029682 
NR in maize $(Z m N R)$ F (forward) - 5'-GCCGAGTCCGACAATTACTAC-3' and R (reverse) - 5'-GCGTCGTTATCACCGAGTTTA-3', and of glutamine synthetase in maize (ZmGln1-3) F-5'-GTGGTATGGTATTGAGCAGGAG-3' and R-5'-CGCCGATTCCACAGTAGTAAG-3', were generated based on the sequences made available in the National Center for Biotechnology Information database (http://www.ncbi.nlm.nih.gov/) at accession numbers AF153448.1 and X65928.1 (Li et al., 1993; Cañas et al., 2009), thereby amplifying fragments with 124 and 94 bp, respectively. Based on earlier studies (Zörb et al., 2005; Shen et al., 2012), the Actin gene (ZmActin) was chosen as the control. The F-5'-GCCACGTACAACTCCATCAT-3' and R-5'GACGTGATCTCCTTGCTCATAC-3' primers of ZmActin amplified fragments of $128 \mathrm{bp}$; ZmActin was found to be stable in the standardization analyses of the assay. All of the primers were designed to intercalate introns and exons to avoid the genomic DNA amplification if this were present. The specificity of each initiator was verified by examining the alignment of its sequences utilizing the function BLASTn of GenBank (Altschul et al., 1997). Besides, a conventional RT-PCR was run with a pool of cDNAs to verify the presence of individual bands on a gel electrophoresis.

\section{qPCR}

Relative quantitative real-time expression was performed on an ABI PRISM 7500 Sequence Detector System (Applied Biosystems). The cDNA samples utilized in the reactions comprised a pool from the three biological repetitions for each genotype/treatment combination. Each reaction comprised the following components: $1 \mu \mathrm{L}$ cDNA, $200 \mathrm{nM}$ of each primer (forward and reverse), $0.4 \mu \mathrm{L}$ ROX Low, and $10 \mu \mathrm{L}$ KAPA SYBR ${ }^{\circledR}$ FAST qPCR Kit Master Mix, with ROX (Kapa Biosystems Inc., Boston, MA, USA). The final volume was made up to $20 \mu \mathrm{L}$. The thermal conditions for the reaction were $2 \mathrm{~min}$ at $50^{\circ} \mathrm{C}, 10 \mathrm{~min}$ at $95^{\circ} \mathrm{C}$, followed by 40 cycles of $15 \mathrm{~s}$ at $95^{\circ} \mathrm{C}$ and $1 \mathrm{~min}$ at $60^{\circ} \mathrm{C}$, finishing with $15 \mathrm{~s}$ at $95^{\circ} \mathrm{C}$. After the relative quantification, a dissociation curve was constructed to verify the quality of the amplified product. All of the assays were conducted in triplicate, and always included the use of control without cDNA on each plate for the detection of possible contamination. The efficiency of the assays was determined with a pool of samples of the cDNAs from the treatments through serial dilution of the cDNA (1:10) and the primers for the target and control sequences. Reaction efficiencies were calculated from the following formula: $E=\left[10^{1 / s l o p e}\right]-1$ (Bustin et al., 2009). Through an examination of the results obtained, it was possible to demonstrate that the target primers and control gene presented similar efficiencies, which were within the acceptable limits so that the assays produced viable results for the quantification of the ESTs.

The results were processed according to the $\Delta \Delta C q$ method, in which the data are normalized to $C q$ values obtained for the control gene. $C q$ is defined as the first amplification cycle in which the fluorescence signal indicates that the PCR product is detected above the threshold. The normalization was performed according to the equation $\Delta C q=C q$ (target gene) - $\mathrm{Cq}$ (control gene; actin). Calibration of $\Delta C q$ for a sample was determined by the formula $\Delta \Delta C q=\Delta C q$ (sample) $-\Delta C q$ (calibrator). Relative quantification (RQ) was obtained as $2^{\Delta \Delta C q}$ (Livak and Schmittgen, 2001). The normalized data obtained through the calculations of the relative quantification of the expression of the ESTs were submitted first to ANOVA followed by the $F$-test $(\mathrm{P} \leq 0.05)$ and thenby a comparison of the mean values by the Tukey test $(\mathrm{P}$ $\leq 0.05$ ). All statistical analyses were performed utilizing the Statistical Analysis System v.8 software (Statistical Analysis System - SAS, 1999).

Genetics and Molecular Research 16 (2): gmr16029682 


\section{RESULTS AND DISCUSSION}

\section{Expression of ESTs related to N metabolism in maize}

\section{$Z m N R$}

Inoculation with $A$. brasilense led to increases in the expression of $Z m N R$ transcripts for the hybrids AG7098 and 2B707. The same was not observed for the varieties: V2 did not respond to the inoculation, while variety V4 presented a higher level of expression only for the case when it received Ntop-dressing without inoculation (Figure 1).

\section{NITRATE REDUCTASE}

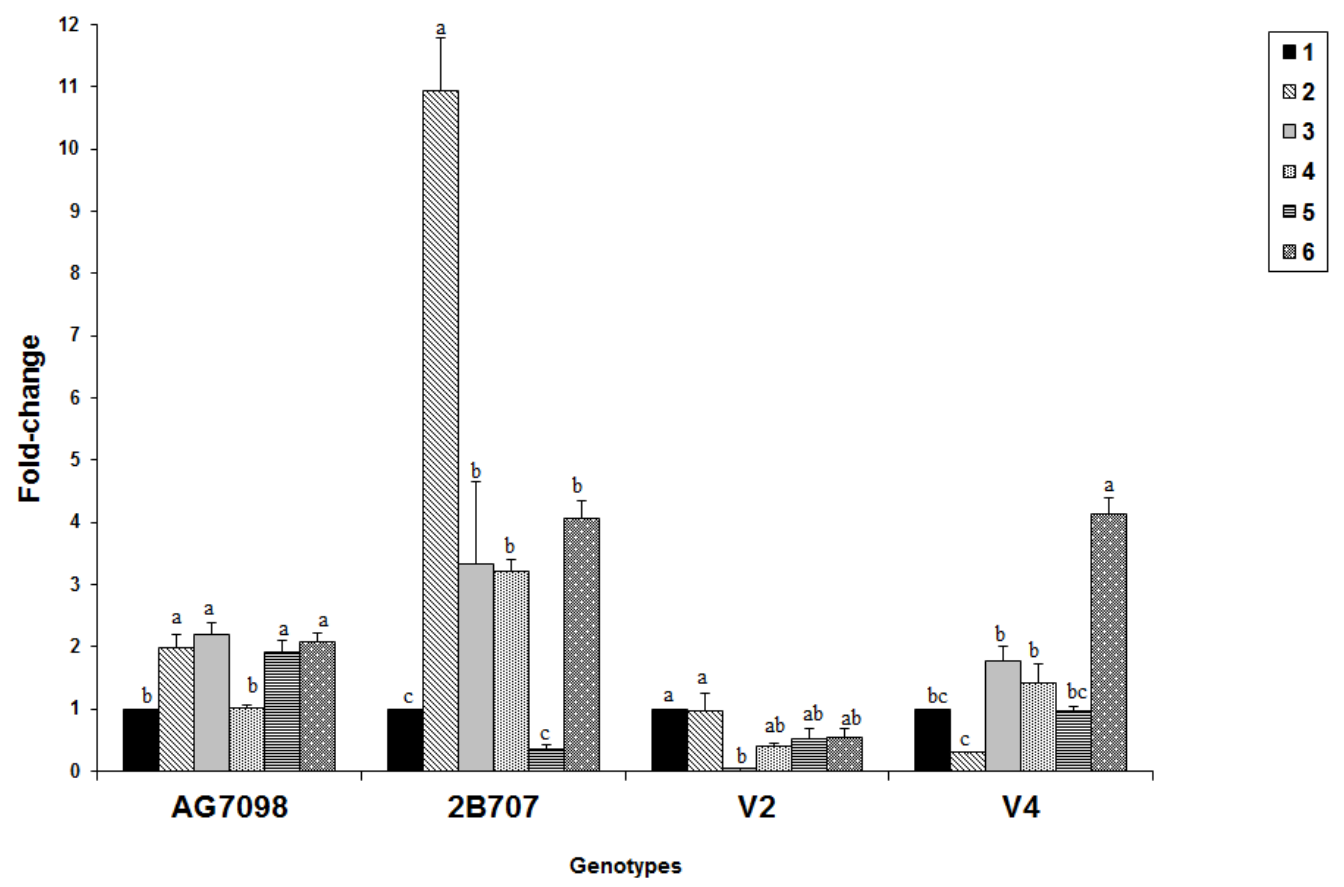

Figure 1. Relative quantitative expression profiles for nitrate reductase $(Z m N R)$ in the leaves of four maize genotypes submitted to different forms of inoculation with Azospirillum brasilense. The forms of inoculation and nitrogen application rates were as follows: 1) Control, no inoculation and no $\mathrm{N}$ top-dressing, 2) Inoculation of the seeds with $A$. brasilense shortly before sewing (b.s.) and no N top-dressing, 3) Seed inoculation and N top-dressing at $100 \mathrm{~kg} / \mathrm{ha} \mathrm{N}$, 4) Inoculation via soil at 30 days after emergence (d.a.e.) and no $\mathrm{N}$ top-dressing, 5) Soil inoculation at 30 d.a.e., with top-dressing of $100 \mathrm{~kg} / \mathrm{ha} \mathrm{N}$, and 6) No inoculation, with top-dressing of $100 \mathrm{~kg} / \mathrm{ha} \mathrm{N}$. The heights of the columns represent the mean induction of gene transcripts related to the control treatment. Columns with the same letter do not differ significantly from others in the same group (genotype - A and C, or treatment - B and D) that bear the same letter when submitted to the Tukey test $(\mathrm{P} \leq 0.05)$. The bars at the top of the columns represent the standard error of the mean indicated by the height of the column.

Genetics and Molecular Research 16 (2): gmr16029682 
For genotype AG7098, the inoculation with A. brasilense via seeds b.s. (Treatments 2 and 3) led to similar levels of expression, independent of the application of fertilizer by topdressing. For inoculation performed via soil at 30 d.a.e., the induction of the expression of $Z m N R$ in AG7098 was only greater when the inoculation was combined with a top-dressing of $100 \mathrm{~kg} / \mathrm{ha} \mathrm{N}$ (Treatment 5), although the induction, in this case, did not differ from AG7098, which received only the nitrogenous top-dressing (Treatment 6) (Figure 1). Inoculation of the seeds of genotype $2 \mathrm{~B} 707 \mathrm{~b}$.s. and without top-dressing (Treatment 2) promoted a significant increase in the level of expression of the $Z m N R$ transcripts, a somewhat smaller increase was registered for three other treatments: inoculation via seeds with top-dressing of $100 \mathrm{~kg} / \mathrm{ha}$ $\mathrm{N}($ Treatment 3), soil inoculation at 30 d.a.e. without $\mathrm{N}$ top-dressing (Treatment 4), and $100 \mathrm{~kg} /$ ha $\mathrm{N}$ alone (Treatment 6) (Figure 1). For the two hybrids evaluated, the results indicate that $\mathrm{N}$ top-dressing might be dispensed with if the seeds were inoculated b.s., since plants raised from inoculated seeds gave the same level of $Z m N R$ expression as plants that received top-dressing.

The experimental varieties, V2 and V4, showed distinct responses related to the treatments applied (Figure 1). For V2, inoculation b.s. did not affect the expression of the $Z m N R$ EST when the inoculation was not accompanied by top-dressing (Treatment 2), but with $\mathrm{N}$ top-dressing (Treatment 3 ) a suppression of the transcripts was observed. The remaining treatments, soil inoculation with $A$. brasilense at 30 d.a.e. with or without topdressing and top-dressing alone (Treatments 4,5 , and 6 ) had no influence on the expression of $Z m N R$ (Figure 1). The general conclusion drawn from these results was that variety V2 did not respond to inoculation with $A$. brasilense. For variety $\mathrm{V} 4$, it was observed that inoculation via seeds b.s. and without $\mathrm{N}$ top-dressing (Treatment 2) gave the lowest level of expression of $Z m N R$. However, inoculation via soil at 30 d.a.e. can be substituted for fertilizer top-dressing, and induce similar levels of $Z m N R$ transcripts. The greatest expression was found in the plants that received only nitrogenous fertilization (Treatment 6) (Figure 1). Taken together, the results suggest that, in the variety $\mathrm{V} 4$, the $Z m N R$ gene was overexpressed in the presence of $\mathrm{N}$ and the absence of $A$. brasilense.

Based on the results obtained, it can be inferred that the increments in the expression of ZmNR EST resulting from the inoculation of maize with $A$. brasilense probably occur through enhanced root development, which gives the roots a greater power to explore the soil and absorb nutrients (Pereira et al., 2015). In the specific case of $\mathrm{NO}_{3}^{-}$, the $\mathrm{N}$ source on which the NR enzyme acts, it is possible that inoculation with $A$. brasilense will have produced an indirect effect on the metabolism of $\mathrm{N}$. It should be noted that the expression of $Z m N R$ corresponds to the capacity of the plant to reduce $\mathrm{NO}_{3}^{-}$for assimilation of the ammonium in the form of organic N, while the expression of the genes that codify GS leads to inferences pertaining to the assimilation of inorganic $\mathrm{N}$ coming from biological fixation or recycling (Masclaux et al., 2000). In maize, the activity of the NR enzyme is induced by the availability of $\mathrm{NO}_{3}^{-}$(Purcino et al., 1994). In experiments examining the effects of $\mathrm{N}$ dose elevation $(75 \%$ $\mathrm{NO}_{3}^{-}, 25 \% \mathrm{NH}_{3}$ ), increases in the enzymatic activity of $\mathrm{NR}$ by $134.2 \%$ have been reported (Majerowiczet et al., 2002).

In maize leaves inoculated with Azospirillum sp, an increase in NR activity followed by rises in the $\mathrm{N}$ levels and production may be indicative of effects due to growth hormones, enhancing the assimilation of nitrate by the plant. On the other hand, increases in foliar $\mathrm{N}$ and production, not accompanied by changes in NR activity, may be attributed to the biological fixation of N (Garcia de Salamone and Döbereiner, 1996). The enzymatic activity of NR in maize was induced when $100 \%$ of the required $\mathrm{N}$ was supplied in the form of $\mathrm{NO}_{3}^{-}$, with no

Genetics and Molecular Research 16 (2): gmr16029682 
effects occurring upon inoculation with the bacteria Azospirillum spp and Herbaspirillum spp (Machado et al., 1998). Inoculation of maize with $A$. amazonense did not influence the activity of the NR enzyme, but when $\mathrm{N}$ was supplied as a formulation, predominantly in the nitrate form, activity of NR was induced (Reis Junior et al., 2008).

Analyzing the responses for differences between the genotypes for each of the applied treatments, it was found that hybrid AG7098 gave the highest expression of $Z m R N$, which comprised inoculation with $A$. brasilense via soil at 30 d.a.e. and top-dressing (Figure 2).

NITRATE REDUCTASE

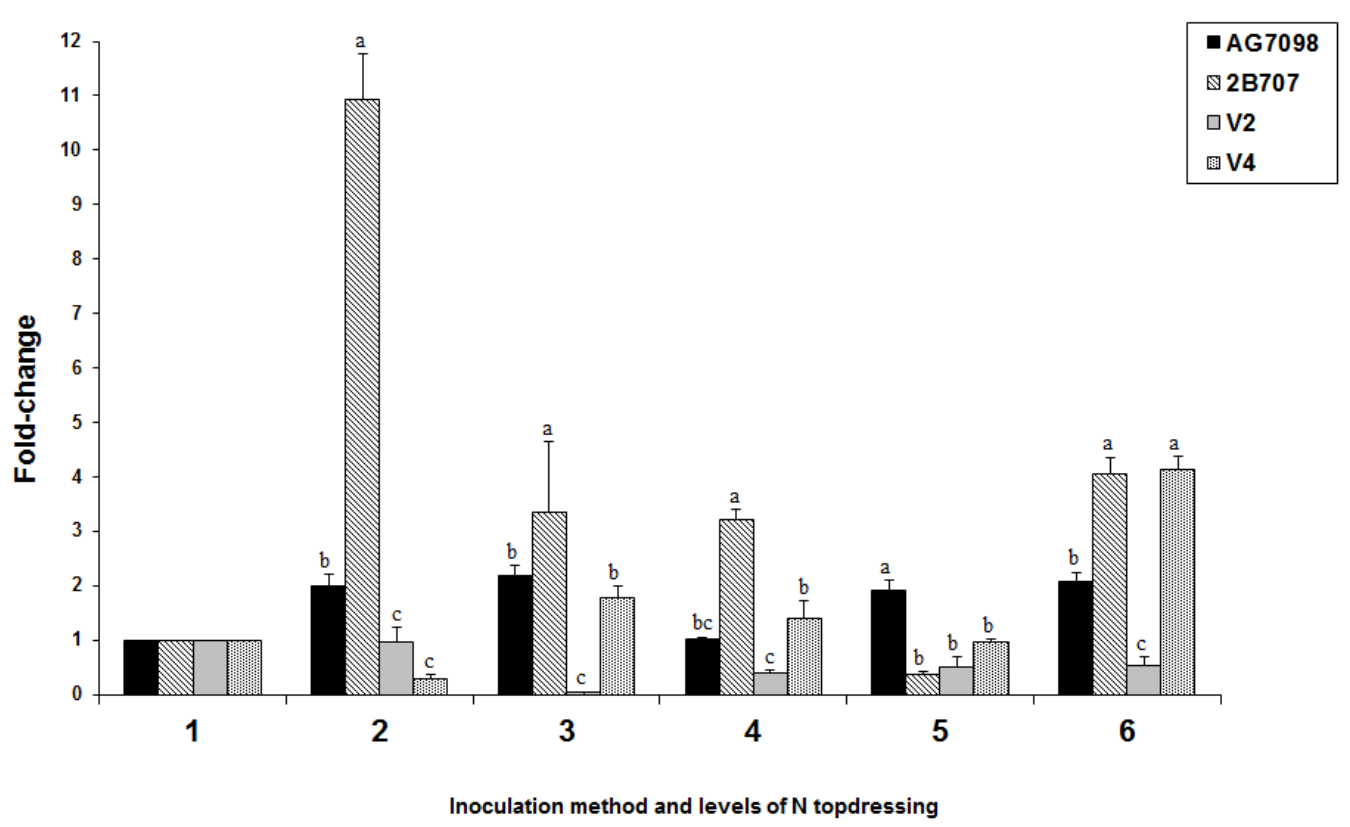

Figure 2. Relative quantitative expression profiles for nitrate reductase $(Z m N R)$ in the leaves of four maize genotypes submitted to different forms of inoculation with Azospirillum brasilense and different levels of application of nitrogenous fertilization. The forms of inoculation and nitrogen application rates were as follows: 1) Control, no inoculation and no $\mathrm{N}$ top-dressing, 2) Inoculation of the seeds with A. brasilense shortly before sewing (b.s.) and no $\mathrm{N}$ top-dressing, 3) Seed inoculation and $\mathrm{N}$ top-dressing at $100 \mathrm{~kg} / \mathrm{ha} \mathrm{N}$, 4) Inoculation via soil at 30 days after emergence (d.a.e.) and no $\mathrm{N}$ top-dressing, 5) Soil inoculation at 30 d.a.e., with top-dressing of $100 \mathrm{~kg} / \mathrm{ha} \mathrm{N}$, and 6) No inoculation, with top-dressing of $100 \mathrm{~kg} / \mathrm{ha} \mathrm{N}$. The heights of the columns represent the mean induction of gene transcripts related tothe control treatment. Columns with the same letter do not differ significantly from others in the same group (genotype - A and C, or treatment - B and D) that bear the same letter when submitted to the Tukey test $(\mathrm{P} \leq$ 0.05). The bars at the top of the columns represent the standard error of the mean indicated by the height of the column.

Hybrid 2B707 displayed the greatest expression of $Z m R N$ when the genotypes were submitted to inoculation with $A$. brasilense b.s., with or without $\mathrm{N}$ top-dressing (Treatments 2 and 3), and when inoculated via soil at 30 d.a.e. without $\mathrm{N}$ top-dressing (Treatment 4), indicating that inoculation with $A$. brasilense has a positive effect on this genotype (Figure 2). The experimental varieties presented underexpression of $Z m R N$ transcripts when submitted to the treatment consisting of seed inoculation b.s. with no nitrogenous fertilization by top-

Genetics and Molecular Research 16 (2): gmr16029682 
dressing (Treatment 2). Comparing all the genotypes, variety V2 presented the lowest values for $Z m R N$ expression for both forms of inoculation, with or without the supply of $\mathrm{N}$ as a fertilizer (Figure 2).

The differentiated responses of genotypes to inoculation with diazotrophic bacteria are explained through the influence of a diversity of factors. These include the genotype and physiological condition of the plant, the strain and physiological condition of the bacteria, the environmental conditions such as light and temperature, as well as the physicochemical properties of the soil such as aeration, moisture content, microbiota, and $\mathrm{N}$ availability. All of these factors are capable of exerting an influence on the success of plant-bacteria associations (Dobbelaere et al., 2001). In the same way, the expression of the genes that codify for NR may be regulated by genetic and physiological factors of the plants and is also strongly related to environmental factors (Cao et al., 2008).

\section{$Z m G \ln 1-3$}

For the hybrids AG7098 and 2B707, and for the variety V4, inoculation with $A$. brasilense induced the expression of ZmGln1-3 transcripts. However, the variety V2 did not respond to the inoculation. The highest levels of expression of the ZmGln1-3ESTs in leaves of the hybrid AG7098 were recorded for the treatments consisting of inoculation with $A$. brasilense b.s. with $\mathrm{N}$ top-dressing (Treatment 3 ) and $\mathrm{N}$ top-dressing alone (Treatment 6 ), followed by the treatment in which $A$. brasilense was applied b.s. and there was no application of $\mathrm{N}$ (Treatment 2). These results suggest that for the genotype AG7098 inoculation of the seeds b.s. has a positive effect on ZmGln1-3 expression. Interestingly, for hybrid 2B707 in the absence of $\mathrm{N}$ top-dressing, both forms of inoculation, b.s. and 30 d.a.e. (Treatments 2 and 4), led to overexpression of the $Z m G \ln 1-3$ transcripts; this indicates that the application of $\mathrm{N}$ may inhibit the activity of the bacteria for genotype 2B707 (Figure 3).

Thus, the contribution of $A$. brasilense to the induction of the expression of the ZmGln1-3 gene is evident. These results corroborate the reported fixation of atmospheric $\mathrm{N}$ by bacteria of the genus Azospirillum when under microaerobic conditions with $\mathrm{N}$ limitation (Steenhoudt and Vanderleyden, 2000).

For the variety V2, the profile of relative quantitative expression for ZmGln1-3 presented the same pattern of variations across the evaluated treatments as seen for the $Z m R N$ ESTs (Figures 1 and 3). Inoculation b.s. with nitrogenous top-dressing (Treatment 3) led to underexpression of $Z m G \ln 1-3$ for genotype V2. Apart from the case of treatment 3, the induction of the expression of the $Z m G \ln 1-3$ gene in variety V2 did not show a response to inoculation with $A$. brasilense. Recognizing that $Z m G \ln 1-3$ is a marker for the process of BFN, this suggests that the association between the V2 genotype and strains AbV5 and AbV6 of $A$. brasilense is not efficient, in the sense of promoting BFN. Turning to variety V4, inoculation b.s. followed by top-dressing 30 days after sewing (Treatment 3 ) induced the highest levels of expression of ZmGln1-3, followed by inoculation via soil at 30 d.a.e. without $\mathrm{N}$ top-dressing (Treatment 4). According to these results, variety V4 responded significantly and positively to the inoculation with A. brasilense, displaying increases in the expression of ZmGln1-3. When the target is the induction of ZmGln1-3 transcripts, if inoculation is performed via soil at 30 d.a.e., then supplying $\mathrm{N}$ by top-dressing may be dispensed with (Figure 3). As was found in the case of hybrid 2B707, the results obtained for variety V4 indicated that supplying $\mathrm{N}$ by top-dressing inhibits the activity of the bacteria.

Genetics and Molecular Research 16 (2): gmr16029682 


\section{GLUTAMINE SYNTHETASE}

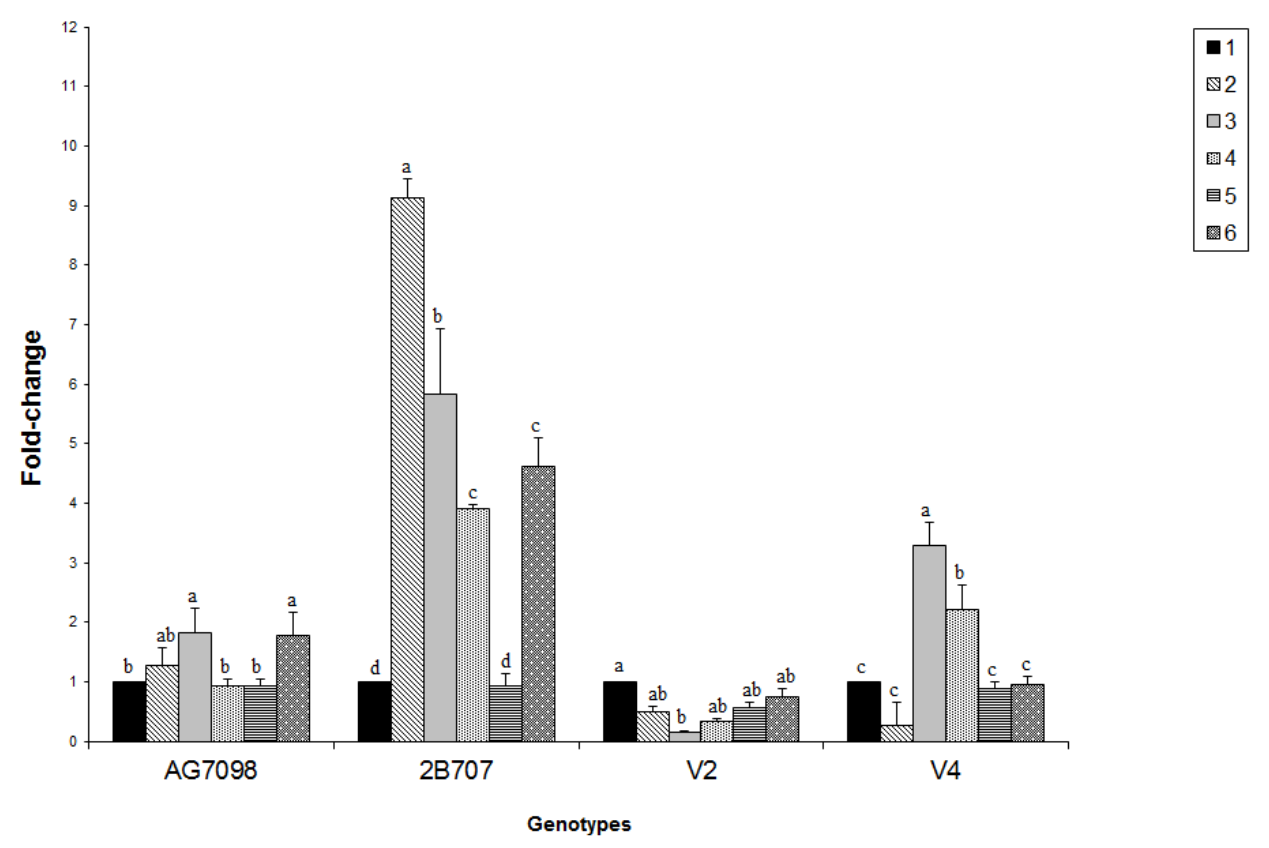

Figure 3. Relative quantitative expression profiles for glutamine synthetase ( $Z m G \ln 1-3)$ in the leaves of four maize genotypes submitted to different forms of inoculation with Azospirillum brasilense and different levels of application of nitrogenous fertilization. The forms of inoculation and nitrogen application rates were as follows: 1) Control, no inoculation and no $\mathrm{N}$ top-dressing, 2) Inoculation of the seeds with $A$. brasilense shortly before sewing (b.s.) and no $\mathrm{N}$ top-dressing, 3) Seed inoculation and $\mathrm{N}$ top-dressing at $100 \mathrm{~kg} / \mathrm{ha} \mathrm{N}$, 4) Inoculation via soil at 30 days after emergence (d.a.e.) and no $\mathrm{N}$ top-dressing, 5) Soil inoculation at 30 d.a.e., with top-dressing of $100 \mathrm{~kg} /$ ha $\mathrm{N}$, and 6) No inoculation, with top-dressing of $100 \mathrm{~kg} / \mathrm{ha} \mathrm{N}$. The heights of the columns represent the mean induction of gene transcripts related tothe control treatment. Columns with the same letter do not differ significantly from others in the same group (genotype - A and C, or treatment - B and D) that bear the same letter when submitted to the Tukey test $(\mathrm{P} \leq 0.05)$. The bars at the top of the columns represent the standard error of the mean indicated by the height of the column.

The presence of N-fixing bacteria can induce the greater activity of GS enzymes so that when there are efficient symbiotic associations there occurs greater provision of $\mathrm{NH}_{4}^{+}$to the plants (Machado et al., 1998).

Analyzing the differences in behavior between the four genotypes for each of the applied treatments as revealed in the expression of the two evaluated ESTs, it could be seen that the profiles for inoculation of the seeds b.s. with $\mathrm{N}$ top-dressing (Treatment 3 ) and inoculation at 30 d.a.e. without top-dressing (Treatment 4) are similar. The profile for inoculation b.s. without top-dressing differs from these, in that underexpression was observed for variety V4 (Figure 4).

In comparison to the varieties V2 and V4, the hybrid AG7098 displayed significant inducement of relative expression of $Z m G \ln 1-3$ when the plants received Treatments 2 and 6. However, there were no treatments for which the relative expression in hybrid AG7098 was greater than for 2B707 (Figure 4). Among the four genotypes, hybrid 2B707 showed the 


\section{GLUTAMINE SYNTHETASE}

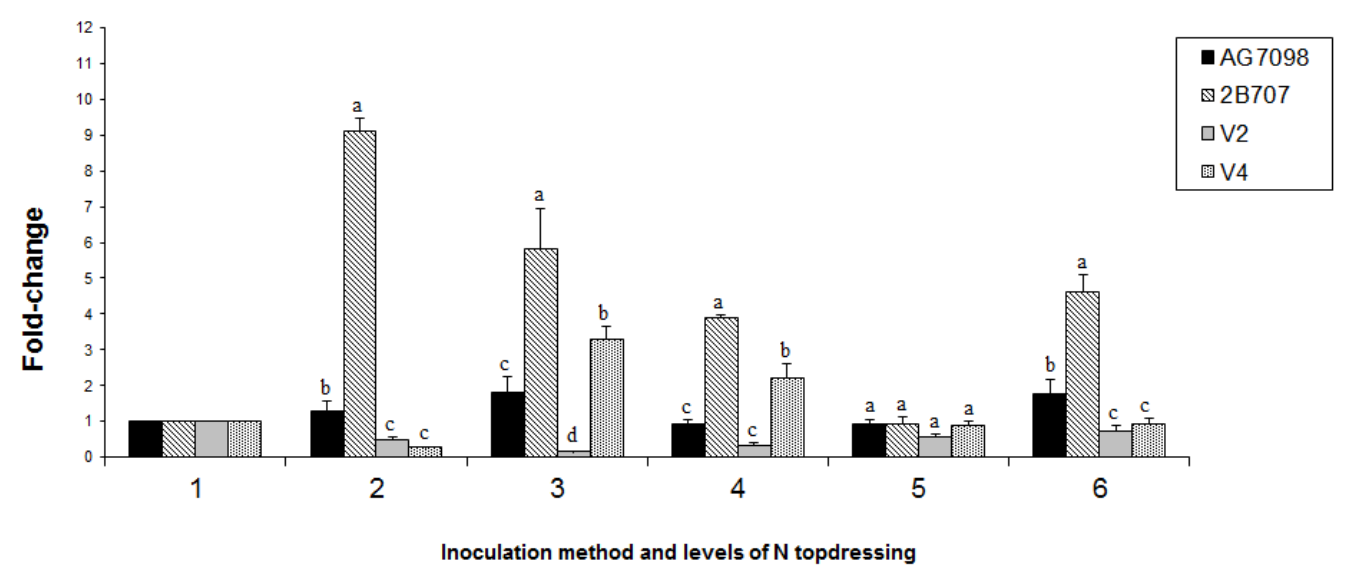

Figure 4. Relative quantitative expression profiles for glutamine synthetase $(Z m G \ln 1-3)$ in the leaves of four maize genotypes submitted to different forms of inoculation with Azospirillum brasilense and different levels of application of nitrogenous fertilization. The forms of inoculation and nitrogen application rates were as follows: 1) Control, no inoculation and no $\mathrm{N}$ top-dressing, 2) Inoculation of the seeds with $A$. brasilense shortly before sewing (b.s.) and no $\mathrm{N}$ top-dressing, 3) Seed inoculation and $\mathrm{N}$ top-dressing at $100 \mathrm{~kg} / \mathrm{ha} \mathrm{N}$, 4) Inoculation via soil at 30 days after emergence (d.a.e.) and no $\mathrm{N}$ top-dressing, 5) Soil inoculation at 30 d.a.e., with top-dressing of $100 \mathrm{~kg} / \mathrm{ha} \mathrm{N}$, and 6) No inoculation, with top-dressing of $100 \mathrm{~kg} / \mathrm{ha} \mathrm{N}$. The heights of the columns represent the mean induction of gene transcripts related to the control treatment. Columns with the same letter do not differ significantly from others in the same group (genotype - A and C, or treatment - B and D) that bear the same letter when submitted to the Tukey test $(\mathrm{P} \leq 0.05)$. The bars at the top of the columns represent the standard error of the mean indicated by the height of the column.

highest level of ZmGln1-3 transcript expression, when submitted to Treatments 2, 3, 4, and 6; this is indicative of a positive effect from the inoculation of this genotype with $A$. brasilense (Figure 4), and the higher values may be directly related to the availability of $\mathrm{NH}_{4}^{+}$. The varieties V2 and V4 presented under expression of ZmGln1-3 transcripts when inoculated via the seeds b.s. and not given nitrogenous fertilization by top-dressing (Treatment 2). Compared to the other three genotypes, the variety V2 presented under expression of ZmGln1-3 for all forms of inoculation, with or without provision of $\mathrm{N}$ via fertilization; the only exception was Treatment 5 (Figure 4). Variety V4 displayed greater levels of ZmGln 1-3 expression, in comparison to AG7098 and V2, when submitted to Treatments 3 and 4, suggesting a better response to inoculation with $A$. brasilense (Figure 4).

Induction of GS enzyme activity in maize has been verified under regimes of high and low $\mathrm{N}$, where it has been found that the increase in foliar $\mathrm{N}$ was proportional to the GS activity (Hirel et al., 2005b). Further, it has been observed that the genes which codify GS1 ( $g \ln 1-3)$ presented greater expression in leaves, independent of the doses of $\mathrm{N}$ and the plant age (Hirel et al., 2005a,b). When $g \ln 1-3$ was constitutively overexpressed in maize leaves, there was a considerable increase $(+30 \%)$ in grain productivity, confirming that the enzyme GS1 has a relevant relationship with grain production in maize (Martin et al., 2006). The provision

Genetics and Molecular Research 16 (2): gmr16029682 
of ammoniacal $\mathrm{N}$ to maize plants has been reported to increase the activity of GS enzymes, but the same was not observed in plants in the presence of $A$. amazonenses; for this case, GS activity was not influenced (Reis Junior et al., 2008).

In contrast, GS activity was greater in the roots of maize plants inoculated with Azospirillum spp and Herbaspirillum spp and the increase correlated positively with bacterial growth (Machado et al., 1998). Symbiotic associations induce or suppress the expression of the genes of important metabolic routes related to $\mathrm{N}$ assimilation, where these routes are also active in non-symbiotic tissues (Bailly et al., 2007).

In general, the four genotypes evaluated in the present study responded to inoculation with $A$. brasilense, but in distinct ways. Given the observed positive associations between A. brasilense and maize cultivation, it will be interesting to define an improvement program directed at the selection of genotypes with the potential to respond to interaction with bacteria of the genus Azospirillum. Targets for this program would be to obtain productivity increases, while possibly reducing the volume of nitrogenous fertilizers applied. Different strains of A. brasilense could also be explored, with the objective of selecting bacteria with the best potential for symbiotic association with maize genotypes, so that the benefits previously demonstrated in studies with other crops can be transferred to and developed in the cultivation of maize.

\section{CONCLUSIONS}

Inoculation of maize with $A$. brasilense did produce an effect on the expression of $Z m N R$ and $Z m G \ln 1-3$ transcripts. The response depended upon the genotype and the manner in which the inoculation was applied. The study was performed using two hybrids and two experimental varieties of maize. For the hybrids, expression of ZmNR and ZmGln1-3 was induced by inoculation with $A$. brasilense. The effects produced in the varieties by inoculation with $A$. brasilense were distinct. ZmNR was induced in variety V4, but for variety V2, inoculation produced no effects on the evaluated transcripts of either ZmNR or ZmGln1-3. The differentiated responses observed for each genotype serve to provide evidence of the importance of searching for efficient associations between maize genotypes and bacteria of the genus Azospirillum.

\section{REFERENCES}

Altschul SF, Madden TL, Schäffer AA, Zhang J, et al. (1997). Gapped BLAST and PSI-BLAST: a new generation of protein database search programs. Nucleic Acids Res. 25: 3389-3402. https://doi.org/10.1093/nar/25.17.3389

Bailly J, Debaud JC, Verner MC, Plassard C, et al. (2007). How does a symbiotic fungus modulate expression of its hostplant nitrite reductase? New Phytol. 175: 155-165. https://doi.org/10.1111/j.1469-8137.2007.02066.x

Baldani JI and Baldani VLD (2005). History on the biological nitrogen fixation research in graminaceous plants: special emphasis on the Brazilian experience. An. Acad. Bras. Cienc. 77: 549-579. https://doi.org/10.1590/S0001$\underline{37652005000300014}$

Bernard SM and Habash DZ (2009). The importance of cytosolic glutamine synthetase in nitrogen assimilation and recycling. New Phytol. 182: 608-620. https://doi.org/10.1111/j.1469-8137.2009.02823.x

Buchanan BB, Gruissem W and Jones RL (2000).Biochemistry and molecular biology of plants. American Society of Plant Physiologists, Rockville.

Bustin SA, Benes V, Garson JA, Hellemans J, et al. (2009). The MIQE guidelines: minimum information for publication of quantitative real-time PCR experiments. Clin. Chem. 55: 611-622. https://doi.org/10.1373/clinchem.2008.112797

Cañas RA, Quilleré I, Christ A and Hirel B (2009). Nitrogen metabolism in the developing ear of maize (Zea mays):

Genetics and Molecular Research 16 (2): gmr16029682 
analysis of two lines contrasting in their mode of nitrogen management. New Phytol. 184: 340-352. https://doi. org/10.1111/j.1469-8137.2009.02966.x

Cao Y, Fan XR, Sun SB, Xu G, et al. (2008). Effect of nitrate on activities and transcript levels of nitrate reductase and glutamine synthetase in rice. Pedosphere 18: 664-673. https://doi.org/10.1016/S1002-0160(08)60061-2

Dalla Santa OR, Soccol CR, Ronzelli P, Junior., Hernández RF, et al. (2004). Effects of inoculation of Azospirillum sp. in maize seeds under field conditions. J. Food Agric. Environ. 2: 238-242.

Dobbelaere S, Croonenborghs A, Thys A, Ptacek D, et al. (2001). Response of agronomically important crops to inoculation with Azospirillum. Aust. J. Plant Physiol. 28: 871-879.

Ferreira VM, Magalhães PC, Durães FOM, Oliveira LEM, et al. (2002). Metabolismo do nitrogênio associado à deficiência hídrica e sua recuperação em genótipos de milho. Cienc. Rural 32: 13-17. https://doi.org/10.1590/S0103$\underline{84782002000100003}$

Garcia de Salamone IE and Döbereiner J (1996). Maize genotype effects on the response to Azospirillum inoculation. Biol. Fertil. Soils 21: 193-196. https://doi.org/10.1007/BF00335934

Hirel B, Bertin P, Quilleré I, Bourdoncle W, et al. (2001). Towards a better understanding of the genetic and physiological basis for nitrogen use efficiency in maize. Plant Physiol. 125: 1258-1270. https://doi.org/10.1104/pp.125.3.1258

Hirel B, Andrieub B, Valadiera MH, Renarda S, et al. (2005a). Physiology of maize II: Identification of physiological markers representative of the nitrogen status of maize (Zea mays) leaves during grain filling. Physiol. Plant. 124: 178-188. https://doi.org/10.1111/j.1399-3054.2005.00511.x

Hirel B, Martin A, Terce-Laforgue T, Gonzalez-Moro MB, et al. (2005b). Physiology of maize I: A comprehensive and integrated view of nitrogen metabolism in a C4 plant. Physiol. Plant. 124: 167-177. https://doi.org/10.1111/j.13993054.2005.00510.x

Hungria M, Campo RJ, Souza EM and Pedrosa FO (2010). Inoculation with selected strains of Azospirillumbrasilense and A. lipoferum improves yields of maize and wheat in Brazil. Plant Soil 331: 413-425. https://doi.org/10.1007/ $\underline{\text { s11104-009-0262-0 }}$

Lana MC, Dartora J, Marini D and Hann JE (2012). Inoculation with Azospirillum, associated with nitrogen fertilization in maize. Rev. Ceres 59: 399-405. https://doi.org/10.1590/S0034-737X2012000300016

Li MG, Villemur R, Hussey PJ, Silflow CD, et al. (1993). Differential expression of six glutamine synthetase genes in Zea mays. Plant Mol. Biol. 23: 401-407. https://doi.org/10.1007/BF00029015

Livak KJ and Schmittgen TD (2001). Analysis of relative gene expression data using real-time quantitative PCR and the 2(-Delta Delta C(T)) Method. Methods 25: 402-408. https://doi.org/10.1006/meth.2001.1262

Machado AT, Sodek L, Dobereiner J and Reis VM (1998). Efeito da adubação nitrogenada e da inoculação com bactérias diazotróficas no comportamento bioquímico da cultivar de milho Nitroflint. Pesqui. Agropecu. Bras. 33: 961-970.

Majerowiczet N, Pereira JMS, Medici LO, Bison O, et al. (2002). Estudo da eficiência de uso do nitrogênio em variedades locais e melhoradas de milho. Rev. Bras. Bot. Braz. J. Bot. 25: 129-136. https://doi.org/10.1590/S0100$\underline{84042002000200002}$

Martin A, Lee J, Kichey T, Gerentes D, et al. (2006). Two cytosolic glutamine synthetase isoforms of maize are specifically involved in the control of grain production. Plant Cell 18: 3252-3274. https://doi.org/10.1105/tpc.106.042689

Masclaux C, Valadier MH, Brugière N, Morot-Gaudry JF, et al. (2000). Characterization of the sink/source transition in tobacco ( Nicotiana tabacum L.) shoots in relation to nitrogen management and leaf senescence. Planta 211: 510518. https://doi.org/10.1007/s004250000310

Masclaux-Daubresse C, Daniel-Vedele F, Dechorgnat J, Chardon F, et al. (2010). Nitrogen uptake, assimilation and remobilization in plants: challenges for sustainable and productive agriculture. Ann. Bot. 105: 1141-1157. https:// doi.org/10.1093/aob/mcq028

Morrison KM, Simmons SJ and Stapleton AE (2010). Loci controlling nitrate reductase activity in maize: ultraviolet-B signaling in aerial tissues increases nitrate reductase activity in leaf and root when responsive alleles are present. Physiol. Plant. 140: 334-341. https://doi.org/10.1111/j.1399-3054.2010.01406.x

Pereira LM, Pereira EM, Revolti LTM, Zingaretti SM, et al. (2015). Seed quality, chlorophyll content index and leaf nitrogen levels in maize inoculated with Azospirillum brasilense. Rev. Cienc. Agron. 46: 630-637.

Purcino AAC, Magnavaca R, Machado AT and Marriel IE (1994). Atividade da redutase do nitrato em genótipos antigos e modernos de milho, cultivados sob dois níveis de nitrogênio. Rev. Bras. Fisiol. Vegetal 6: 41-46.

Reis Junior FB, Machado CTT, Machado AT and Sodek L (2008). Inoculação de Azospirillum amazonense em dois genótipos de milho sob diferentes regimes de nitrogênio. Rev. Bras. Ciênc. Solo 32: 1139-1146. https://doi. org/10.1590/S0100-06832008000300022

Roesch LF, Camargo F, Selbach P, Sá ES, et al. (2005). Identificação de cultivares de milho eficientes na absorção de nitrogênio e na associação com bactérias diazotróficas. Cienc. Rural 35: 924-927. https://doi.org/10.1590/S0103$\underline{84782005000400028}$

Genetics and Molecular Research 16 (2): gmr16029682 
Shen Y, Jiang Z, Yao X, Zhang Z, et al. (2012). Genome expression profile analysis of the immature maize embryo during dedifferentiation. PLoS One 7: e32237 https://doi.org/10.1371/journal.pone.0032237.

Statistical Analysis System - SAS (1999). User's Guide: Statistics. 6th edn. SAS, Cary.

Steenhoudt O and Vanderleyden J (2000). Azospirillum, a free-living nitrogen-fixing bacterium closely associated with grasses: genetic, biochemical and ecological aspects. FEMS Microbiol. Rev. 24: 487-506. https://doi. org/10.1111/j.1574-6976.2000.tb00552.x

Walker V, Couillerot O, Von Felten A, Bellvert F, et al. (2012). Variation of secondary metabolite levels in maize seedling roots induced by inoculation with Azospirillum, Pseudomonas and Glomus consortium under field conditions. Plant Soil 356: 151-163 https://doi.org/10.1007/s11104-011-0960-2.

Zörb C, Noll A, Karl S, Leib K, et al. (2005). Molecular characterization of $\mathrm{Na}+/ \mathrm{H}+$ antiporters $(\mathrm{ZmNHX})$ of maize (Zea mays L.) and their expression under salt stress. J. Plant Physiol. 162: 55-66. https://doi.org/10.1016/j. jplph.2004.03.010

Genetics and Molecular Research 16 (2): gmr16029682 